\title{
Contribution of uric acid to cancer risk, recurrence, and mortality
}

\author{
Mehdi A Fini', Anthony Elias ${ }^{2}$, Richard J Johnson ${ }^{3}$ and Richard M Wright ${ }^{4 *}$
}

\begin{abstract}
Two risk factors for the development and progression of cancers that are amenable to life style modification are chronic inflammation and the metabolic syndrome. This review proposes two new targets that may mechanistically integrate inflammation and metabolic syndrome, have been largely ignored, and are known to be druggable. Recent evidence has demonstrated that elevated serum uric acid (hyperuricemia) is associated with excess cancer risk, recurrence, and mortality. Although uric acid (UA) can function as a systemic antioxidant, its pro-inflammatory properties have been postulated to play an important role in the pathogenesis of cancer. Furthermore, obesity, Type 2 Diabetes Mellitus (T2DM), and the metabolic syndrome (MetS) are also associated with excess cancer, chronic inflammation, and with hyperuricemia, suggesting that UA may represent an important link between these disorders and the development of cancer. While pharmacological modulation of hyperuricemia could in principal augment anti-cancer therapeutic strategies, some cancer cells express low intracellular levels of the enzyme Xanthine Oxidoreductase (XOR) that are associated with increased cancer aggressiveness and poor clinical outcome. Thus, systemic pharmacological inhibition of XOR may worsen clinical outcome, and specific strategies that target serum uric acid (SUA) without inhibiting tumor cell XOR may create new therapeutic opportunities for cancer associated with hyperuricemia. This review will summarize the evidence that elevated SUA may be a true risk factor for cancer incidence and mortality, and mechanisms by which UA may contribute to cancer pathogenesis will be discussed in the hope that these will identify new opportunities for cancer management.
\end{abstract}

Keywords: Cancer, Obesity, T2DM, Metabolic syndrome, Uric acid

\section{Review}

Hyperuricemia and cancer

UA is derived exclusively from the oxidation of xanthine and hypoxanthine by XOR [1], and pharmacological inhibition of XOR has been used extensively for the management of hyperuricemic disorders such as gout, nephrolithiasis, some cases of acute and chronic kidney disease, ischemia-reperfusion disorders, and others [2,3]. In 1982 UA was hypothesized by Ames et al. to provide a primary defense against human cancer based upon its capacity to scavenge singlet oxygen, its capacity to inhibit lipid peroxidation, and its high serum concentration in humans [4]. Extensive support for the physiological antioxidant function of UA was generated

\footnotetext{
* Correspondence: richard.m.wright@ucdenver.edu

${ }^{4}$ Department of Medicine, Pulmonary Division and Webb-Waring Center, University of Colorado Denver, Anschutz Medical Campus, V20, Room 3105, Mail stop C-322 12850 East Montview Boulevard, Aurora, CO 80045-0511, USA Full list of author information is available at the end of the article
}

in the ensuing dozen years since publication of this hypothesis, and the protective antioxidant properties of UA have been identified in many different organ systems [5]. Nonetheless, elevated serum urate, the dominant monosodium form of UA at physiological $\mathrm{pH}$, was found to exhibit strong statistical association with increased premature cancer death in both men and women [6-8] suggesting a more complex role for UA in cancer biology than that of a general antioxidant (Table 1).

In humans, normal SUA levels are commonly between 178 and $360 \mu \mathrm{M}$, (3 and $6.8 \mathrm{mg} / \mathrm{dl})$ with higher levels found in males and postmenopausal females than in premenopausal females. Frank hyperuricemia (SUA levels > $360 \mu \mathrm{M}$ ) can reach levels of $700 \mu \mathrm{M}$ or higher and are associated with increasing risk for gout and acute kidney injury arising from the deposition of monosodium urate (MSU) crystals in the renal tubules and interstitium [9]. Mechanisms inducing MSU crystal formation and deposition are complex and not simply an automatic 
Table 1 References demonstrating the specific association of SUA with cancer risk, recurrence, and mortality

\begin{tabular}{|c|c|c|c|c|}
\hline Reference & Risk category & Gender & Cancer type & SUA measurement \\
\hline Petersson et al., 1983 & Unselected & M & All & Concurrent \\
\hline Petersson et al., 1984 & Unselected & M & All & Concurrent \\
\hline Levine et al., 1989 & Unselected & $\mathrm{F}$ & All & Prospective \\
\hline Kolonel et al., 1994 & Unselected & M & Prostate & Prospective \\
\hline Korenga et al., 2005 & $A B C G 2$ & $M / F$ & Renal & Prospective \\
\hline Tsimberidou et al., 2005 & MetS/Obesity & $M / F$ & All & Prospective \\
\hline Shin et al., 2006 & Unselected & $\mathrm{M} / \mathrm{F}$ & All & Concurrent \\
\hline Giovannucci, 2007 & MetS & $M / F$ & Colon & Prospective \\
\hline Hu et al., 2007 & $A B C G 2$ & $M / F$ & B-Cell Lymphoma & Prospective \\
\hline Rose et al., 2007 & MetS & $\mathrm{F}$ & Breast & Concurrent \\
\hline Strasak et al., 2007a & Unselected & $\mathrm{F}$ & All & Prospective \\
\hline Strasak et al., 2007b & Unselected & M & All & Prospective \\
\hline Boffetta et al., 2009 & Gout & $M / F$ & All & Prospective \\
\hline Becker et al., 2009 & Obesity & $M / F$ & All & Concurrent \\
\hline Strasak et al., 2009 & Unselected & $M / F$ & All & Prospective \\
\hline Bjorge et al., 2011 & MetS & $\mathrm{F}$ & Breast & Concurrent \\
\hline Hammarsten et al., 2011 & MetS & M & Prostate & Prospective \\
\hline Panero, et al., 2011 & T2DM & $M / F$ & All & Prospective \\
\hline Siddiqui, 2011 & MetS & $M / F$ & Colorectal & Prospective \\
\hline Wang, et al., 2011 & ABCG2 & $M / F$ & Leukemia & Prospective \\
\hline
\end{tabular}

consequence of hyperuricemia [10]. More recently there has been increasing interest that high to high normal levels of SUA (310-330 $\mu \mathrm{M})$, below those associated with MSU crystal deposition, may have contributory roles in acute renal injury [11], chronic kidney disease $[12,13]$, hypertension [14], cardiovascular disease (CVD) [15-17], and MetS [18-20]. While hyperuricemia is increased by age, menopause, alcohol consumption, and other dietary factors, as a component of MetS, hyperuricemia is associated with increased risk of colorectal, breast, prostate, and other cancers [21-25].

Although early reports established an epidemiological association between SUA and age, sex, and increased death due to cancer of all types [6,7], numerous confounding factors including diet, alcohol consumption, and underlying co-morbidity disorders like diabetes, CVD, or MetS may have been responsible for the observed association. Furthermore, cancer itself could promote hyperuricemia through cancer related cell death rather than being an independent risk factor for the development of cancer. It is important to recognize in passing that both of these early reports and subsequent studies that observed an association between SUA and death due to cancer also observed an inverse relation with serum cholesterol $[6,7,26]$. While these publications did not explain the inverse association with cholesterol, it is possible that the cachexia of cancer, which is associated with reduced fat stores and muscle wasting, releases glutamate and glutamine that can increase SUA levels, and indeed elevated SUA has been associated with sarcopenia [27]. On the other hand, in vitro analysis of liver tissue slices demonstrated that UA itself inhibited cholesterol biosynthesis upstream of mevalonic acid, possibly by inhibition of hydroxymethylglutaryl CoA reductase [28], suggesting a potentially broad effect of UA on cholesterol level.

Data from prospective studies, however, do suggest that SUA may predict the development of cancer. After adjusting for a large number of confounding factors, Levine et al. [8] observed that SUA measured prospectively at baseline before the development of cancer was significantly associated with all site cancer mortality over 11.5 years of follow-up in women aged 55-64, and was, therefore, unlikely to reflect hyperuricemia developed secondarily to the development of cancer. A similar prospective analysis in Japanese men used the Cox Proportional Hazard Ratio (HR) to identify an association of elevated SUA with the risk for development of prostate cancer over a period of ten years following baseline measurement [29]. Similarly, the increase in incident prostate cancer observed in a Swedish cohort of MetS males was associated with high SUA and insulin levels, and both SUA and insulin were significant parallel prospective markers of risk for prostate cancer. Indeed, a 
SUA level above $358 \mu \mathrm{M}$ was found by binary regression analysis to be an independent and significant $(\mathrm{p}<0.04)$ prospective risk factor for incident prostate cancer [21]. Further and much larger prospective studies conducted on both male and female European cohorts confirmed that high SUA $(>6.71 \mathrm{mg} / \mathrm{dl}$ in men and $>5.41 \mathrm{mg} / \mathrm{dl}$ in women) measured at baseline was an independent risk factor for death from all cancers compared to high normal SUA $(4.6 \mathrm{mg} / \mathrm{dl})$ [30,31]. These studies achieved very high significance (adjusted $\mathrm{HR}, \mathrm{p}<0.0001$ ) comparing death ten years after measurement of antecedent SUA, and as also noted by Levine [8], the strongest association between baseline SUA and cancer death was achieved in the older patient quartile. These studies were important as well because SUA obtained at baseline was derived from apparently healthy people.

Important advances in statistical methods were subsequently employed to identify both the dose dependence and time varying association of SUA and risk for all site cancer mortality [32]. Finely stratified SUA obtained at baseline and with 18.5 years of follow-up demonstrated the impact of SUA on risk for cancer mortality at both high and very low UA levels (J-Shaped dose-response curve). This study was the first to identify SUA as both a time dependent co-variant risk factor for overall cancer incidence and one exhibiting a clear dose-response to baseline SUA. Furthermore, amongst patients already exhibiting terminal end stage cancer, weekly measurement of SUA from the day of admission to cancer associated death revealed that high SUA $(>7.2 \mathrm{mg} / \mathrm{dl})$ significantly and independently predicted reduced survival time [26], revealing yet another dimension to the risk for cancer mortality by elevated SUA.

Collectively, these data identify elevated SUA to be independently and significantly associated with the risk for all site cancer incidence and mortality when measured in advance of the development of cancer. While the incidence of cancer and cancer mortality observed in hyperuricemia do not support the hypothesis that the antioxidant properties of UA provide anti-cancer defense in humans [4], the increment in cancer seen by Strasak et al. [32] at low dose SUA may suggest a protective effect of SUA that is optimal near the normal human levels of SUA. Furthermore, since low SUA may also reflect poor nutrition, these observations raise the possibility that a low SUA might have been a sentinel sign prior to the recognition of cancer.

\section{SUA, inflammation, and cancer}

The association of elevated SUA with increased cancer risk and mortality predicts that diseases associated with hyperuricemia would also exhibit excess cancer risk and mortality. Obesity, T2DM, insulin resistance, hypertension, MetS, and gout comprise a cluster of syndromes that are associated with hyperuricemia, chronic inflammation, and activated innate immunity $[33,34]$ that may be mediated in part by UA [35-38]. Elevated SUA has been associated with prepubertal obese children presenting with insulin resistance [39], and it was identified as a strong and reliable biomarker of MetS in obese young women [40]. Meta-analyses have consistently shown that SUA is a potent independent predictor of hypertension, insulin resistance, and diabetes [41,42]. Furthermore, confirmatory factor analysis of selected variables has identified UA as a single common factor linking four of the core components in the definition of MetS including the HOMAR-IR measure of insulin resistance, mean arterial pressure, the ratio of serum triglycerides to HDLcholesterol, and waist circumference [43]. Experimental evidence is building that this factor could indeed represent UA, and recent analysis has identified its potential phyiological role in T2DM and related disorders [44].

Excess cancer risk and incidence have been associated with obesity, T2DM, insulin resistance, MetS, and gout in large epidemiological analyses. For example, increased all site cancer incidence has been observed in a large cohort of both male and female gout patients, and increased overall cancer risk persisted in this population throughout the 5 to 15 year follow-up from the time of gout diagnosis [45]. The British Heart Disease and Diabetes Indicators Screened Cohort study (HDDRISC) identified a cluster of biomarkers comprising numerous inflammatory markers including SUA. SUA independently and as a component of the biomarker cluster was predictive of all site cancer mortality in T2DM patients through 21.5 years of follow-up [46]. This study also confirmed the significant inverse relationship between cancer mortality, SUA, and serum cholesterol in diabetic patients. In a smaller but significant study of T2DM patients from Northern Italy, high SUA was found to be strongly associated with increased mortality that was almost entirely the result of all site neoplastic disease. Statistically significant increased cancer risk and mortality was observed for SUA levels above $226 \mu \mathrm{M}$ that persisted through the highest SUA quartile [47]. These data confirmed a massive study conducted earlier by the Cancer Prevention Study II of 1.2 million US men and women that identified diabetes as an independent predictor of mortality from cancer of the colon, pancreas, breast, liver, and bladder [48]. Although the CPS-II did not compile data on SUA per se, a wide range of dietary and lifestyle covariant parameters were included in the analysis that have been found independenly to promote hyperuricemia, including obesity, lack of exercise, western diet, red meat consumption, and alochol consumption. Obesity, T2DM, insulin resistance, and MetS have been specifically associated with increased risk of breast cancer (BC) $[22,36,49-52], \mathrm{BC}$ recurrence [53,54], and 
more aggressive tumor biology $[55,56]$. The Triple Negative Breast Cancer subtype that exhibits poor prognosis, excess recurrence and metastasis, and worse chemotherapeutic response was significantly more prevalent in patients exhibiting MetS $[36,57,58]$.

Chronic low grade inflammation is an underlying component of obesity, T2DM, insulin resistance, and MetS that is mediated in part by the pro-inflammatory properties of UA [35-38]. UA has been found to promote inflammation in two ways: as an MSU crystal or as a soluble factor. Recent data have consolidated the idea that the MSU crystal functions as a "danger signal" recognized by Toll receptor- $4[9,10,59]$ and contributing to many inflammatory disorders. Dead and dying cells have been postulated as one source of UA in an inflammatory microenvironment, and activation of Toll receptors by MSU crystals has been found to stimulate leukocyte pro-inflammatory cytokine production $[59,60]$. On the other hand, in its soluble form, UA was found to enter cells where it activated MAP kinases (p38 and ERK), stimulated NFkB, and induced expression of inflammatory mediators including MCP-1 and C-Reactive Protein (CRP) [61-64]. These effects were likely mediated by NADPH oxidase induced oxidative stress inside the cell $[61,62,65,66]$. Importantly, additional in vivo studies further demonstrated that lowering UA pharmacologically improved inflammation both in laboratory animals and in patients with chronic kidney disease $[13,67]$. Inflammatory processes induced by UA in its soluble form require the function of transport proteins (GLUT9, URAT1, and others) that translocate soluble UA into cells activating wide genetic reprogramming and is therefore mechanistically distinct from Toll receptor activation by MSU crystals [68,69]. Adiponectin, C-Reactive Protein, and Leptin are key components of the chronic inflammatory environment that have been associated with elevated SUA levels and cancer.

\section{Adiponectin, SUA, and cancer}

Adiponectin is an anti-inflammatory protein whose levels are reduced in obesity, T2DM, insulin resistance, and MetS [70] and when reduced it has been associated with increased risk of diverse cancers [71-73]. Reduced circulating adiponectin was associated with the risk for hypertension and renal injury, and it was inversely associated with Leptin and CRP levels [74]. Low adiponectin levels were found to be inversely associated with high SUA in both young obese children and in adult women presenting with MetS $[70,75]$. Therefore, it is highly significant that in mouse models of MetS UA per se was found to specifically reduce serum adiponectin level [67], suggesting a functional link between SUA and adiponectin expression.
High circulating levels of adiponectin have been strongly linked to improved BC risk and outcome $[23,36,76]$, and adiponectin treatment was found to attenuate both cancer cell proliferation and mammary tumor progression in xenograft analysis of aggressive BC cells in mice [77]. The antitumor properties of adiponectin may be in part related to its capacity to inhibit tumor angiogenesis [78]. On the other hand, low circulating adiponectin level has been a commonly observed risk factor for BC [53,79-81]. Although most commonly associated with post-meopausal BC $[23,76,80]$, low serum adiponectin was associated with increased $\mathrm{BC}$ risk in both pre- and post-menopausal Japanese patients [81]. Low circulating adiponectin was associated with increased BC risk overall [53,79-81], BC recurrence and metastasis [53,82], and increased $\mathrm{BC}$ mortality [79]. In transgenic mouse models of mammary tumorigenesis that utilized the MMTV driven polyoma middle-T antigen, haploinsufficiency of adiponectin was found to accelerate mammary tumor onset and increase aggressiveness and tumor development [83]. Furthermore, increased lung metastases were observed by a different group of investigators using the same model of mammary tumorigenesis [84]. This group made the apparently contradictory observation that haploinsufficiency of adiponectin produced a delayed angiogenic response, an observation that was explained as a potential angio-mimetic property of adiponectin acting in the early, but not late, stages of tumor vascularization [85]. Current data indicate that adiponetin may in part exert its effects on mammary tumor cells by inhibition of Wnt signalling, Akt activity, and the tumor suppressor LKB1 $[77,82]$. Furthermore, loss of adiponectin has been found to promote hyperactivation of PI3K/Akt phosphorylation and signalling that was associated with increased proliferation of mammary tumor cells [83]. Together, these data are consistent with a role for high SUA in depressing circulating adiponectin level that is in turn associated with increased tumorigenesis, tumor size, and metastasis.

\section{C-reactive protein, SUA, and cancer}

Elevated SUA has been specifically associated with high circulating levels of the pro-inflammatory mediator CReactive Protein (CRP) as well as the pro-inflammatory mediators IL-6 and TNF $\alpha$ in a large cross-sectional European cohort [86]. Co-expression of high CRP and elevated SUA was identified in patients with T2DM [87] or MetS [88-90] where it was specifically associated with CVD or insulin resistance. Elevated levels of CRP were positively associated with increased BC risk and risk of cancer death $[36,91]$, and they were positively correlated with SUA levels in early and advanced stages of BC [92]. High circulating levels of CRP were also associated with 
increased risk for colorectal [93], lung [94], gastric [95], and renal cell cancers [96]. Significantly, pharmacolological inhibition of XOR with allopurinol concomittantly reduced both SUA and CRP in patients with either normal renal function or in patients expressing chronic kidney disease [13,97,98], and direct support for a functional role of UA in the production of CRP was obtained in vascular smooth muscle cells and endothelial cells where UA stimulated secretion of CRP as well as MCP-1 [61,62].

Despite these strong associations between CRP, SUA, and the risk for diverse types of cancer, CRP is unlikely to be a specifc cause of cancer. Analysis of the four most common single nucleotide polymorphisms (SNPs) found in the CRP gene that were associated with increased circulating CRP (95\% CI of 58-87\% increase) revealed that there was no increase in cancer risk or incidence associated with these SNPs [99]. This study employed a large European cohort of 10,215 subjects and demonstrated an insignificant odds ratio for cancer associated with doubling of CRP level of 0.94 (95\% CI of 0.81 to 1.08). While these data indicated that elevated CRP per se was unlikely to be a cause of cancer, they did identify CRP as an important prognostic biomarker of outcome that revealed an underlying inflammatory process associated with high SUA levels [100].

\section{Leptin, SUA, and cancer}

Leptin has been described as the missing link between hyperuricemia and obesity, MetS, T2DM, and related disorders [101,102]. Leptin is the product of the Obese gene (ob), and loss of function mutations in mouse and human ob genes results in profound obesity and T2DM $[103,104]$. Deficiency in receptors for leptin $\left(\operatorname{LepR}^{\mathrm{db}-\mathrm{db}}\right.$ and Lepr ${ }^{\mathrm{db}-\mathrm{lb}}$ ) in mice likewise result in obesity, diabetes, pre-diabetes, and MetS $[67,105]$. Thus, it has been postulated that while leptin and leptin receptor signaling act to suppress food intake and maintain long-term energy balance, the excess serum leptin found in obesity may reflect a state of leptin resistance [104].

Leptin, CRP, and SUA are directly correlated in patients presenting with MetS [40,74,106-108], and inversely correlated with adiponectin level $[75,107]$. Leptin has been postulated to be a key mediator linking obesity and hyperuricemia as a potential regulator of SUA level. Statistical models have revealed strong positive association between circulating leptin and SUA, and in multifactorial regression analyses serum leptin could explain $34-42 \%$ of the variance in SUA in both men and women in a hypertensive cohort of Turkish patients [101]. Leptin and SUA were strongly associated in healthy and T2DM subjects [102], in patients presenting with MetsS, central obesity, and insulin resistance $[109,110]$, and indeed in a Japanese cohort of patients with gout, gout was associated with excess MetS compared to normal controls and was strongly associated with elevated leptin and SUA [111].

There is some evidence that the rise in uric acid may be the consequence of elevated leptin levels because loss of leptin receptor signaling also engenders hyperuricemia [67]. Fruehwald-Schultes et al. [102] have suggested a mechanism that may in part explain this observation. They have postulated that leptin may directly impair UA excretion in the kidney and that in obesity elevated leptin levels may impair renal clearance of UA resulting in hyperuricemia. Hyperuricemic, leptin receptor deficient mice also show excessive hepatic XOR expression suggesting that leptin receptor signaling may also down regulate hepatic XOR expression [67]. Thus, leptin may affect SUA at both the level of production and renal clearance. Taken together, these results suggest an additional link between SUA and cancer: with leptin regulating SUA levels in subjects with obesity, MetS, and T2DM.

There is also experimental evidence that UA may have a role in mediating leptin resistance. Recent studies have reported that elevated SUA precedes the development of MetS in humans [42], suggesting that it might precede the development of leptin resistance. Experimental studies found that lowering SUA pharmacologically improved features of MetS in rats in response to fructose feeding, including the development of insulin resistance, hypertriglyceridemia, and elevated blood pressure [19]. More recently, a pilot study found that lowering SUA in fructose-fed rats also reduced leptin expression in visceral fat tissues [112]. Further studies will be required to determine if the reduced leptin expression would also translate into reduced leptin resistance.

The pro-tumorigenic role of leptin on breast, colon, prostate, and ovarian cancer in patients with obesity, MetS, and T2DM was recently reviewed $[85,113,114]$. Briefly, mounting evidence suggests that the leptin to adiponectin ratio is sensitive to states of obesity, T2DM, and MetS and that the ratio is a key clinical determinant of cancer tumorigenesis and/or carcinogenesis with elevated leptin being associated with greater cancer risk and poor outcome. The pro-tumorigenic effect of leptin appears to be mediated in part by its stimulation of cancer cell proliferation via ERK, JNK, and STAT3 pathways. While leptin is an apparent growth factor for BC that is elevated in $\mathrm{BC}$ patients [36,115], its mechanism of tumor promotion remains equivocal [36]. Importantly, leptin receptors are expressed on many cancer cells including those of the breast [116], and exposure of MCF-7 BC cells to leptin induced cell proliferation that was mediated in part by activation of MAPK [117]. As described below, we speculate that leptin may further 
stimulate proliferation and tumorigenesis by downregulating cancer cell XOR.

\section{UA transport and cancer}

Homeostasis of SUA in humans is maintained by the bidirectional flux of SUA in renal proximal tubule epithelial cells. Presently, no less than 10 plasma membrane transport proteins have been found to contribute to UA movement into and out of the renal proximal tubule epithelial cells [68]. Roles for the Organic Anion Transport (OAT) proteins OAT-1, -3, -4, 10, ABCG2, NPT1/4, MRP4, URAT1, and GLUT9 in renal UA homeostasis and extra-renal distribution are only partially understood. For many of these, a large array of accessory proteins has been identified that are required for cotransport function [68]. The two major renal transporter proteins identified to date are the high affinity transporter URAT1 (SLC22A12) that mediates uptake of urate from the urine into the renal proximal tubular cell, and GLUT9 (SLC2A9/URATv1) which is a voltagesensitive uniporter that mediates the export of UA from the proximal tubular cell into the circulation $[118,119]$. The association of URAT1 or GLUT9 with cancer remains largely untested at the present time.

The ABCG2 locus encoding a member of the ATPbinding cassette transporter proteins, also known as the Breast Cancer Resistance Protein (BCRP), has been intensively studied for its role in resistance to cancer chemotherapy. ABCG2 is an important efflux transporter of xenobiotic compounds, including many antineoplastic drugs, and its inhibition or mutation can improve cancer chemotherapy [120]. Genome wide association studies (GWAS) for hyperuricemia identified ABCG2 as tightly associated with hyperuricemia and gout [121-124]. Functional analysis confirmed the principal role of ABCG2 in normal physiology, independent of drug efflux, as that of UA efflux. These studies identified several SNP associated with the ABCG2 locus that were functionally involved in UA efflux. In particular, SNP rs2231142 generated the C421A DNA mutation causing the Q141K amino acid substitution. Q141K both reduced ABCG2 expression and blocked UA efflux, and it is a common polymorphism causing gout and hyperuricemia in Caucasian, Black, Japanese, and Chinese populations [121-124].

Prospective analysis of the C421A polymorphism in untreated patient populations, those not undergoing any chemotherapeutic drug treatment, demonstrated significant and markedly increased risk for developing nonpapillary renal cell carcinoma [125], an increased risk and poor survival prognosis for patients with diffuse large Bcell lymphoma [126], and increased risk and poor survival prognosis for patients with acute leukemia [127]. These data strongly support the premise that hyperuricemia can be an important risk factor for cancer incidence and mortality, and they underscore the importance of conducting more expansive analysis of other UA transport proteins in diverse cancer settings.

Together these data suggest a model by which both extracellular UA and intracellular UA may collaborate in transformation toward a highly aggressive cancer (Figure 1). Inflammatory stress induced by elevated intracellular UA may promote transformation, while elevated extracellular UA may further stimulate tumor cell proliferation, migration, and survival contributing to the development of highly aggressive cancer.

\section{Tumor cell XOR, UA, and cancer}

Although the increased cancer burden associated with hyperuricemia in obesity, T2DM, and MetS has suggested the relevance of modulating XOR activity in cancer therapy, presently available strategies may be inappropriate for many types of cancer. Allopurinol and febuxostat are FDA approved systemic pharmacological inhibitors that block XOR activity in all cells of the body $[2,128]$. However, inhibition of XOR in tumor cells per $s e$ is a potentially confounding factor that limits current strategies for the pharmacological control of SUA in cancer management.

Decreased or absent tumor cell XOR has been observed in the most aggressive human breast cancer [129], gastric cancer [130], colorectal cancer [131], ovarian cancer [132], non-small-cell lung cancer [133], and in rat hepatic cancer $[134,135]$. For breast, gastric, colorectal, ovarian, and lung cancers in humans the decreased XOR activity was associated with worse clinical prognosis and unfavorable outcome (reduced survival). Poor XOR expression was also associated with poorly differentiated breast, gastric, and colorectal cancers and was associated with over two fold increased risk of distant metastasis. While it has been suggested that the decreased purine catabolism and increased activity of salvage pathway enzymes would favor tumor cell growth $[134,135]$, the decreased XOR activity observed in highly aggressive cancer cells appears to exert unexpected effects on cancer cell differentiation that also favors tumorigenesis and metastasis.

High levels of XOR were found to repress and low levels of XOR to stimulate $\mathrm{BC}$ cell aggressiveness in vitro as measured by increases in COX-2, MMP-1 secretion, and in vitro migration rate [136], and this appears to reflect the unexpected role played by XOR in $\mathrm{BC}$ cell differentiation. XOR activity was found to modulate expression of the inhibitor of differentiation protein, Id1. High levels of Id1 have been linked to highly aggressive and metaplastic $\mathrm{BC}$, and the inhibition of Id 1 by epithelial XOR was postulated to reduce $\mathrm{BC}$ aggressiveness and/or metastasis. Furthermore, loss of XOR 


\section{Transformation}

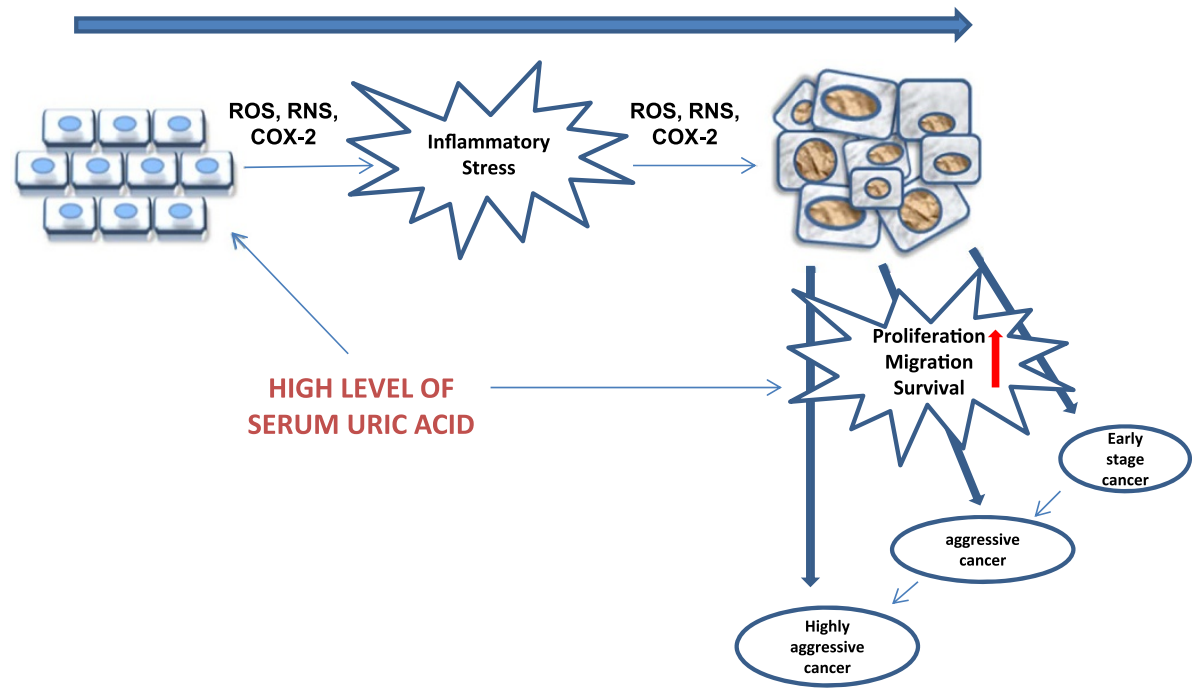

Figure 1 Hyperuricemia contributes to tumorigenesis by promoting both transformation and tumor cell proliferation, migration, and survival. High levels of extracellular UA present in the serum or in the local microenvironment of tumor cells exerts many pro-inflammatory effects that contribute to tumorigenesis. While extracellular UA has antioxidant effects that may protect normal cells from transformation, entry of UA into cells can generate inflammatory stress that arises from the effects of intracellular UA on ROS/RNS generation and COX-2 activation. Stimulation of cancer cells by UA further promotes proliferation, migration, and survival that mediates progression from early stage cancer to highly aggressive cancer.

expression in $\mathrm{BC}$ cells in vitro resulted in stimulation of Id1 level and increased BC cell aggressiveness [137]. Remarkably, epithelial XOR has now been found to modulate three of the critical signature genes mediating $\mathrm{BC}$ aggressiveness and metastasis: COX-2, MMP-1, and Id1 $[136,137]$ consistent with the observed increase in clinical recurrence and metastasis in poor XOR expressing cancers. These data indicate that systemic pharmacological inhibition of XOR with the goal of reducing SUA might exacerbate tumorigenesis or metastasis by inhibition of tumor cell XOR.

Little is known about the response of cancer cells themselves to UA. UA present in the tumor microenvironment may contribute to tumorigenesis or metastasis in ways that are distinct from the pro-inflammatory processes elicited by SUA. Exposure of human mammary cancer cells or mouse mammary epithelial cells in vitro to a wide concentration range of UA dose dependently increased migratory rate of both cells [136]. Migratory rate of both cells was significantly increased at even low normal levels of UA. Thus, treatment of BC cells with exogenous UA in vitro appeared to replicate the state of cells from more aggressive tumors with increased metastasis that have been associated with aggressive breast and colorectal cancer in patients with MetS $[23,138,139]$. It was postulated that the high levels of SUA observed in obesity, T2DM, and MetS may repress tumor cell XOR and inhibit its function in promoting epithelial cancer cell differentiation [136], and it has been shown that physiological levels of UA can indeed repress XOR activity [140]. However, it can be imagined as well that highly aggressive tumor cells that are naturally deficient in XOR expression [134-136] may be both poorly set up to promote differentiation but still capable of responding to exogenous UA by increased aggressiveness. Furthermore, we postulate that the elevated levels of leptin found in obesity, T2DM, and MetS may collaborate with UA and contribute to tumorigenesis and metastasis by down regulation of tumor cell XOR. Taken together these data suggest a mechanism by which diminished tumor cell XOR in conjunction with hyperuricemia and elevated leptin promote cancer cell proliferation, migration, and survival (Figure 2).

\section{The special cases of leukemia and tumor lysis syndrome}

Certain leukemias and the Tumor Lysis Syndrome are cancer states that are also associated with severe hyperuricemia. In these cases, the hyperuricemia arises as a result of cell lysis, release of purines, and subsequent UA accumulation. XOR plays a prominent role in both cancer types as the source of UA, and current therapies are directed at inhibition of XOR with allopurinol or Febuxostat and degradation of the SUA using recombinant uricase (Rasburicase). Recent reviews provide excellent discussion of both cancer states and therapeutic 


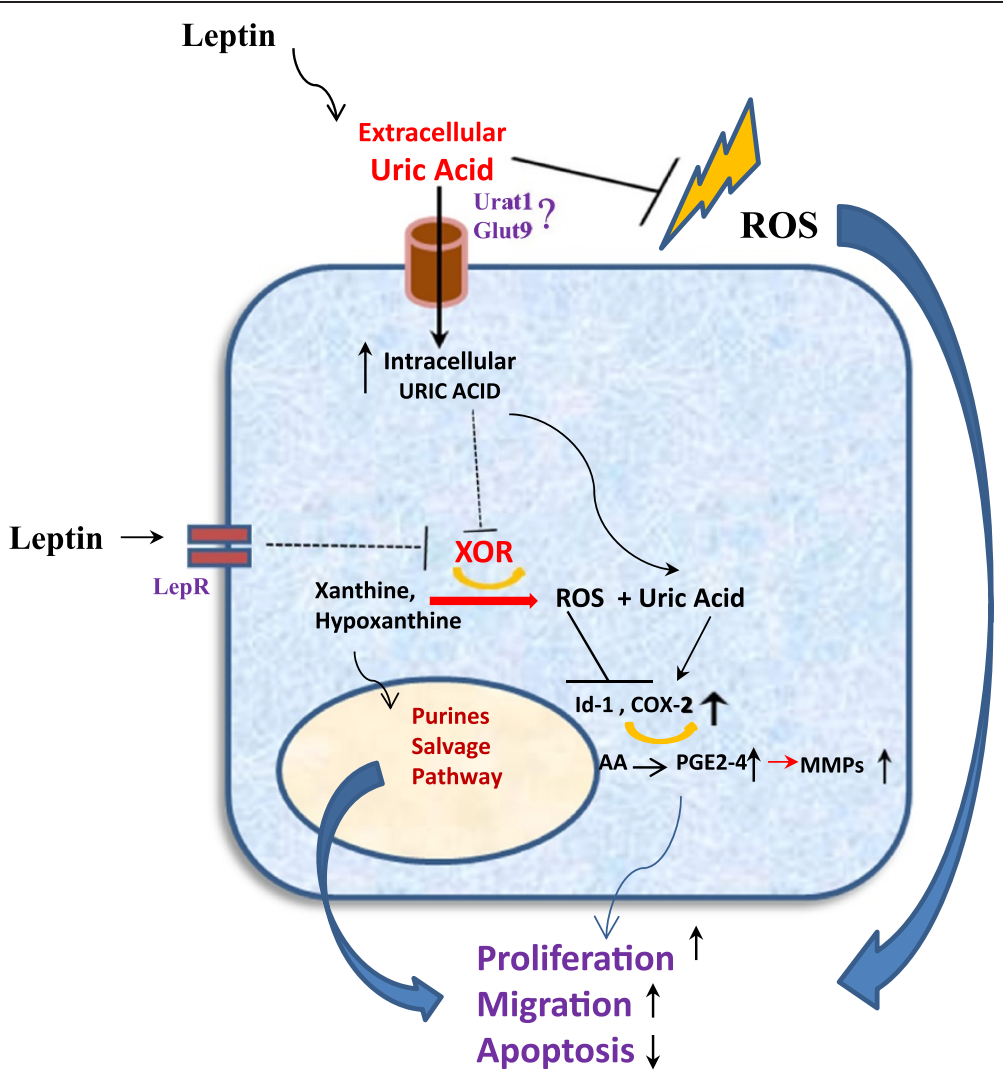

Figure 2 Elevated UA and reduced intracellular XOR contribute to tumor cell proliferation, migration, and survival. ROS scavenging properties of extracellular UA are postulated to promote cancer cell growth and survival in part by protecting cells from oxidative stress induced apoptosis. This arises because tumor cells in general exhibit poor capacity to survive oxidative stress compared with normal cells and may therefore be protected by the antioxidant ROS scavenging properties of UA (J-Shaped dose-response curve; [32]). Loss of XOR expression in the most aggressive cancer cells also contributes to tumor cell proliferation, migration, and survival. In cells showing high level XOR expression, XOR modulates COX-2 and MMP expression reducing migratory activity [136]. However, loss of XOR expression in cancer cells increases COX-2 levels, MMP expression, and migratory activity. Loss of XOR expression may arise for many reasons, including the entry of UA into cancer cells. Import of UA into XOR deficient cancer cells may further promote proliferation and survival in part by stimulating expression of COX-2. The diminished XOR expression found in aggressive cancer cells would result in shunting the XOR substrates hypoxanthine and xanthine into the salvage pathway, providing substrates for nucleotide synthesis, tumor growth, and proliferation. The independent effects of leptin on cancer cells notwithstanding $[85,113]$, the elevated levels of leptin observed in MetS associated cancer may also drive these processes both by inducing hyperuricemia and by down regulating cancer cell XOR.

strategies for reducing the associated hyperuricemia $[141,142]$.

\section{UA as a signaling molecule}

Low physiological levels of UA stimulated mammary cancer cell aggressiveness in vitro, and in cells expressing UA transport proteins capable of importing UA, UA derived from the serum, tumor associated adipocytes, macrophages, or other cells may also stimulate tumorigenesis and/or metastasis. At the present time, very little is known about the mechanisms by which UA may signal to cancer cells. However, some key observations have been generated from non-cancerous cells that may provide a useful background for further studies conducted on cancer cells themselves.

\section{Renal epithelial cells}

Uptake of UA by primary renal proximal tubule epithelial cells (PTEC) of the rabbit inhibited in vitro cell proliferation that was mediated by at least two signaling mechanisms [143]. Cell proliferation was inhibited over a broad concentration range of UA, achieved significance at $100 \mu \mathrm{M}$, and was profound at the hyperuricemic level of $500 \mu \mathrm{M}$. Co-treatment of PTEC with pharmacological inhibitors demonstrated that the inhibition of PTEC proliferation by UA was mediated by the transient activation of MAP Kinases p38, JNK, and ERK1/2. This effect was apparently transduced by UA activation of protein kinase $\mathrm{C}$, cytoplasmic phospholipase $\mathrm{A} 2$, and NF- $\mathrm{kB}$ that was interpreted to comprise divergent pathways. A more complete picture of the response of PTEC to UA was obtained using a 
proteomic approach for UA treated HK-2 cell cultures [69]. Stable heavy isotope labeling of HK-2 cells was achieved using [13 C6]-Lys (heavy) labeling combined with exposure to $500 \mu \mathrm{M}$ UA. Cells were mixed with control cells (no UA and Lys light), proteins prepared, trypsin digested, fractionated by liquid chromatographymass spectrometry (LC-MS), and quantified by the relative ratio of isotopic peptide pairs. After correction for false discovery rate 782 proteins (of 13,652 peptides) were found altered by exposure to UA. Pathway network and functional group analysis identified 42 proteins associated with cell proliferation and 49 with apoptosis placing MAPK and NF-kB signaling networks at the center of UA signaling in PTEC. While details of this analysis remain to be fully deciphered, they establish the primacy of proliferation and apoptosis pathways regulated by UA in renal PTEC.

\section{Vascular Smooth Muscle Cells}

Perhaps the earliest observation that UA signaling may be involved in cell proliferation was generated by the observation that primary rat aortic vascular smooth muscle cell (VSMC) proliferation was stimulated by UA over a concentration range of 50 to $300 \mu \mathrm{M}$, an effect transduced in part by UA activation of cMyc and PDGF Achain [144]. Unlike the human VSMC, rat VSMC do not express the URAT1 transporter or members of the OAT family, and a voltage sensitive transporter (possibly GLUT9 or URAT) may instead mediate UA induced proliferation [145]. Careful preparation of crystal free UA enabled the identification of signaling pathways induced by UA in rat VSMC [61]. NF- $\mathrm{kB}, \mathrm{AP}-1$, and the MAP kinases $\mathrm{p} 38$ and ERK-1/2 were activated by UA at levels from 100 to $700 \mu \mathrm{M}$. In addition to its effects on VSMC proliferation, UA was also found to activate the pro-inflammatory mediators MCP-1 and COX-2 [145].

\section{Adipocytes}

In differentiated mouse 3 T3-L1 derived adipocytes, but not undifferentiated 3 T3-L1 cells, UA was found to induce phospho-activation of $\mathrm{p} 38$ and ERK-1/2 MAP Kinases by a pathway involving activation of the $\mathrm{NADPH}$ oxidase and ROS generation [63]. Induction proceeded over a UA concentration range of 100 $700 \mu \mathrm{M}$ and was blocked by URAT1 inhibition with probenecid. While UA induced an apparent oxidative and nitrosative stress, it was also found subsequently to activate the inflammatory state of these cells [67]. UA at both normo- and hyperuricemic levels simultaneously increased steady state mRNA expression of the leukocyte chemokine MCP-1 and decreased expression of the antiinflammatory protein adiponectin, and these data were largely replicated in an in vivo mouse model. Induction of MCP-1 was sensitive to both superoxide scavenging and apocynin inhibition as well as the PPARy agonist rosiglitazone suggesting the involvement of the NADPH oxidase/ROS system and PPAR $\gamma$, while inhibition of adiponectin appeared to involve PPAR $\gamma$ alone. These observations are consistent with the observed role of intracellular XOR in promoting $3 \mathrm{~T} 3-\mathrm{L} 1$ differentiation and adipogenesis in vivo in mice, an effect that was mediated in part by regulation of PPAR $\gamma$ activity [146]. While XOR dependent redox mechanisms were implicated in adipogenesis, the potential impact of UA per se on adipocyte differentiation has not been determined.

\section{Leukocytes}

While leukocytes exhibit a well-characterized inflammatory response to MSU crystals [10,59], exposure of RAW264.7 mouse macrophages and differentiated human U937 cells to pH adjusted and crystal free UA revealed a dramatic effect on macrophage inflammatory polarization [147]. UA from 30 to $1000 \mu \mathrm{M}$ dose dependently modulated levels of the macrophage M2 polarization markers Arginase-1, CD36, and CD206, and this effect was transduced in part by inhibition of PPAR $\gamma$ sumoylation, an effect that promoted the inflammatory M1 state. Although the identity of the UA transporter mediating the response to UA was not identified, GLUT9 is expressed on leukocytes and remains a reasonable candidate for this function [148]. As an endogenous product of leukocytes, XOR activity exerts many effects on inflammatory potential, cytokine synthesis, and lipid uptake $[147,149,150]$. Because treatment of mouse macrophages with oxonic acid, an inhibitor of uricase, replicated many of the effects of exogenous UA, it was postulated that intracellular UA was in part responsible for the effects of endogenous XOR generated UA on leukocyte function.

\section{UA as an Intracellular Redox Signal}

While the detailed mechanism by which UA contributes to intracellular signaling networks is unknown, it has been postulated to involve intracellular redox dependent mechanisms. For example, in 3 T3-L1 derived adipocytes UA uptake was associated with intracellular ROS accumulation, and inhibition with apocynin implicated the $\mathrm{NADPH}$ oxidase as a source of ROS and placed ROS generation upstream of NF- $\mathrm{kB}, \mathrm{p} 38$, and ERK-1/2 MAP Kinase activation [63,67]. These observations dovetail well with data generated in renal epithelial cells that identified several redox sensitive components of the upstream network mediating MAPK activation that are induced by UA [69]. For example, RAC1, MAPK1, MAP2K, MAP4K were all induced by UA and are known to exhibit redox-sensitive activation that in turn promotes phospho-activation of p38 and ERK-1/2 MAPK [151]. Although not well understood, induction 
of intracellular UA accumulation in pancreatic cancer cells (PANC-1) following radiation exposure or treatment with 5-fluorocracil was found to mediate the induction of MHC class-I related proteins MICA/B that in turn promoted sensitivity to NK-92 cell killing [152]. While the signaling mechanism responsible for the inductive effect of UA on MICA/B expression were not identified, marked elevation in MICA/B protein levels were clearly evident that were inhibited by treatment with allopurinol in vitro.

\section{Conclusions}

Two risk factors for the development and progression of breast cancers that are amenable to life style modification are chronic inflammation and the metabolic syndrome. To ameliorate inflammation, clinical trials abound that focus on COX-2 inhibition. The principal factors felt to mediate cancer risk from metabolic syndrome have included insulin resistance, high IGF1R signaling and higher tissue levels of estrogen (for breast cancer). This review proposes two new targets that may mechanistically integrate inflammation and metabolic syndrome, have been largely ignored, and are known to be druggable. Realization of the important role played by UA as a signaling molecule mediating the inflammatory effects of hyperuricemia in adipocytes and leukocytes, as well as in signaling to cancer cells (Figure 3 ) has emphasized the relevance of managing UA therapeutically which could significantly improve treatment strategies for cancer that is associated with hyperuricemic disorders.

Significant side effects of systemic chronic inhibition of XOR have been recognized for many years. Confounding problems associated with chronic inhibition of XOR include diarrhea, diminished renal function, leukopenia, hypersensitivity reactions, vasculitis [3], and even exacerbation of vascular injury through recently identified effects on nitrite reduction [153]. While the frequency of allopurinol hypersensitivity syndrome may be significantly reduced by avoiding the administration of allopurinol to subjects bearing the HLA-B58 haplotype [154], it remains a serious syndrome with high mortality. Systemic pharmacological inhibition of cancer cell XOR could theoretically exacerbate tumorigenesis, metastasis, and mortality. These unwanted side effects underscore the urgent need for mechanism based preclinical studies that can identify optimal strategies for management of hyperuricemia in relevant cancer models. Recently developed conditional knockout models for XOR that are based on CRE/Lox technology may be of

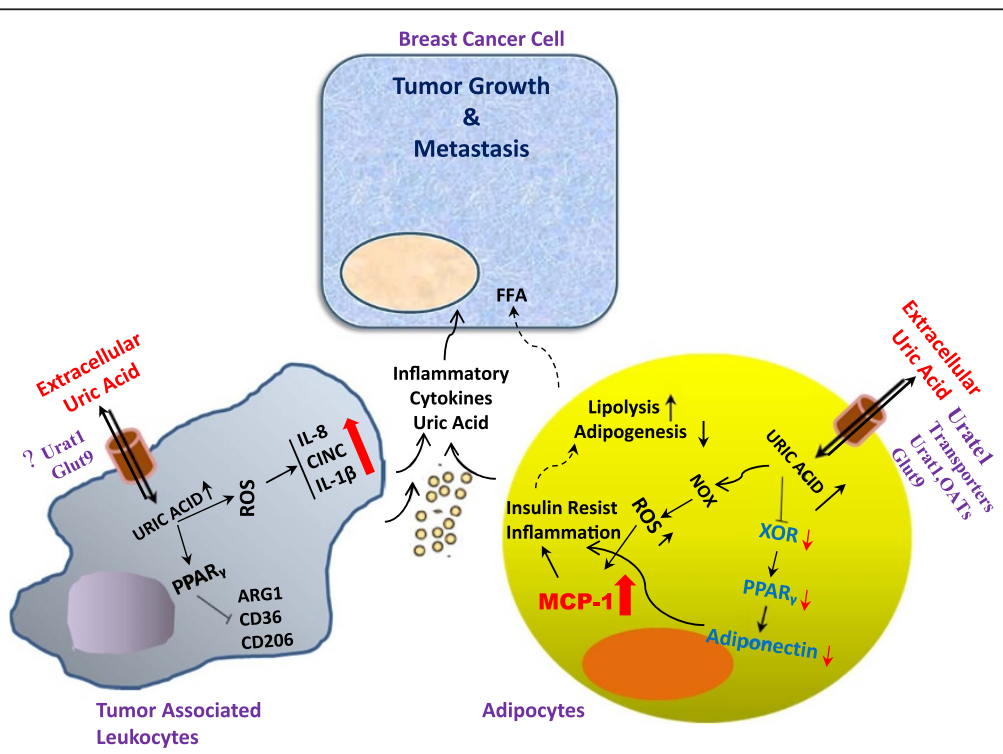

Figure 3 Hypothesis for the protumorigenic role of UA in the breast cancer microenvironment. UA is postulated to enter tumor associated and/or distant adipocytes through a UA-specific transporter (likely URAT1) where it activates the NADPH Oxidase (NOX), generating ROS. As observed in other inflammatory environments, UA at both normo- and hyperuricemic levels may simultaneously increase steady state mRNA expression of the leukocyte chemokine MCP-1 and decrease expression of the anti-inflammatory protein adiponectin. In addition, UA entering adipocytes may down-regulate expression of XOR which is known as a crucial upstream regulator of PPAR- - , a master regulator of adipogenesis and adiponectin expression. Furthermore, as previously shown, UA may reduce levels of the macrophage antiinflammatory markers Arginase-1, CD36, and CD206, an effect transduced in part by inhibition of PPARy sumoylation that in turn promotes macrophage inflammatory activation. Presently, the identity of the UA transporter mediating macrophage response to UA has not been identified. As an endogenous product of leukocytes, XOR activity may exert many effects on inflammatory potential, cytokine synthesis, and lipid uptake. Together, these findings support the hypothesis that hyperuricemia might be partially responsible for the low grade inflammation present in the breast tumor microenvironment that contributes to tumor cell proliferation and metastasis. 
particular value for the knockdown of XOR in specific target cells, such as hepatocytes or adipocytes, that are principal sources of SUA [137]. Likewise, similar CRE/ Lox technology applied to the GLUT9 transporter [155] will be highly valuable in delineating the role of SUA in pre-clinical models of human cancer as well. The goal of specifically managing SUA without exacerbating tumorigenesis and/or metastasis will undoubtedly involve novel therapeutic strategies, but these efforts could significantly improve therapeutic strategy for cancer associated with obesity, T2DM, and MetS.

\section{Abbreviations}

UA: Uric Acid; SUA: Serum Uric Acid; XOR: Xanthine Oxidoreductase; T2DM: Type 2 Diabetes Mellitus; MetS: Metabolic Syndrome; MAPK: Mitogen Activated Protein Kinase; ROS: Reactive Oxygen Species; VSMC: Vascular Smooth Muscle Cell; CVD: CardioVascular Disease; BC: Breast Cancer; CRC: Colorectal Cancer; CRP: C-Reactive Protein; MSU: Monosodium Urate.

\section{Competing interests}

The authors declare no financial or non-financial competing interests. Dr. Johnson holds patent applications related to lowering uric acid in the treatment of metabolic syndrome, kidney disease and hypertension, and has consulted for Ardea, Novartis, Danone, and Astellas. He also holds a patent for the use of allopurinol to treat primary hypertension with the University of Washington and Merck, Inc. Dr. Wright holds a USA clinical use patent $(10 / 573,354)$ for modulating XOR in diverse inflammatory settings.

\section{Authors' contributions}

The authors contributed equally to the research, writing, and review of this manuscript. All authors read and approved the final manuscript.

\section{Acknowledgements}

This work was supported by grants from The Robert and Helen Kleberg Foundation (RW), The National Institutes of Health (HL58547, RW; HL68607, RJ). Dr. Fini was supported by grants from the American Cancer Society (PF-08- 112-01-CCE) and the National Institutes of Health (T32-HL007171).

\section{Author details}

'Department of Medicine Pulmonary Division and Cardiovascular Pulmonary Research Laboratory, University of Colorado Denver, Anschutz Medical Campus, V20, Room 3104, Mail stop C-322 12850 East Montview Boulevard, Aurora, CO 80045-0511, USA. ${ }^{2}$ Martha Cannon Dear Professor of Medicine, Medical Director, Breast \& Sarcoma Programs, Associate Director of Cancer Center for Clinical Sciences, AOP-3115, MS F-724 1635 Aurora Court, Aurora, CO 80045, USA. ${ }^{3}$ Tomas Berl Professor of Medicine, Chief, Division of Renal Diseases and Hypertension, University of Colorado Denver, Anschutz Medical Campus, Mail Stop C281, 12700 E 19th Ave, Room 7015, Aurora, CO 80045-0511, USA. ${ }^{4}$ Department of Medicine, Pulmonary Division and WebbWaring Center, University of Colorado Denver, Anschutz Medical Campus, V20, Room 3105, Mail stop C-322 12850 East Montview Boulevard, Aurora, CO 80045-0511, USA.

Received: 3 May 2012 Accepted: 17 July 2012

Published: 15 August 2012

\section{References}

1. Hille R: Molybdenum-containing hydroxylases. Arch Biochem Biophys 2005, 433(1):107-116.

2. Oxipurinol: alloxanthine, Oxyprim, oxypurinol. Drugs R D 2004, 5(3):171-175.

3. Pacher P, Nivorozhkin A, Szabo C: Therapeutic effects of xanthine oxidase inhibitors: renaissance half a century after the discovery of allopurinol. Pharmacol Rev 2006, 58(1):87-114.

4. Ames BN, Cathcart R, Schwiers E, Hochstein P: Uric acid provides an antioxidant defense in humans against oxidant- and radical-caused aging and cancer: a hypothesis. Proceedings of the National Academy of Sciences of the United States of America 1981, 78(11):6858-6862.
5. Becker BF: Towards the physiological function of uric acid. Free radical biology \& medicine 1993, 14(6):615-631.

6. Petersson B, Trell E: Raised serum urate concentration as risk factor for premature mortality in middle aged men: relation to death from cancer. Br Med J (Clin Res Ed) 1983, 287(6384):7-9.

7. Petersson B, Trell E, Henningsen NC, Hood B: Risk factors for premature death in middle aged men. Br Med J (Clin Res Ed) 1984, 288(6426):1264-1268.

8. Levine W, Dyer AR, Shekelle RB, Schoenberger JA, Stamler J: Serum uric acid and 11.5-year mortality of middle-aged women: findings of the Chicago Heart Association Detection Project in Industry. J Clin Epidemiol 1989, 42(3):257-267.

9. Terkeltaub R: Update on gout: new therapeutic strategies and options. Nat Rev Rheumatol 2010, 6(1):30-38.

10. Ghaemi-Oskouie F, Shi Y: The role of uric acid as an endogenous danger signal in immunity and inflammation. Curr Rheumatol Rep 2011, 13(2):160-166.

11. Shimada M, Dass B, Ejaz AA: Paradigm shift in the role of uric Acid in acute kidney injury. Semin Nephrol 2011, 31(5):453-458.

12. Kang DH, Nakagawa T, Feng L, Watanabe S, Han L, Mazzali M, Truong L, Harris R, Johnson RJ: A role for uric acid in the progression of renal disease. J Am Soc Nephrol 2002, 13(12):2888-2897.

13. Goicoechea M, de Vinuesa SG, Verdalles U, Ruiz-Caro C, Ampuero J, Rincon A, Arroyo D, Luno J: Effect of allopurinol in chronic kidney disease progression and cardiovascular risk. Clin J Am Soc Nephrol 2010, 5(8):1388-1393.

14. Mazzali M, Hughes J, Kim YG, Jefferson JA, Kang DH, Gordon KL, Lan HY, Kivlighn S, Johnson RJ: Elevated uric acid increases blood pressure in the rat by a novel crystal-independent mechanism. Hypertension 2001, 38(5):1101-1106.

15. Fang J, Alderman MH: Serum uric acid and cardiovascular mortality the NHANES I epidemiologic follow-up study, 1971-1992. National Health and Nutrition Examination Survey. JAMA 2000, 283(18):2404-2410.

16. Feig DI, Kang DH, Johnson RJ: Uric acid and cardiovascular risk. The New England journal of medicine 2008, 359(17):1811-1821.

17. Hoieggen A, Alderman MH, Kjeldsen SE, Julius S, Devereux RB, De Faire $U$, Fyhrquist F, Ibsen $\mathrm{H}$, Kristianson $\mathrm{K}$, Lederballe-Pedersen $\mathrm{O}$, et al: The impact of serum uric acid on cardiovascular outcomes in the LIFE study. Kidney Int 2004, 65(3):1041-1049.

18. Stellato D, Morrone LF, Di Giorgio C, Gesualdo L: Uric acid: a starring role in the intricate scenario of metabolic syndrome with cardio-renal damage? Intern Emerg Med 2012, 7(1):5-8.

19. Nakagawa T, Hu H, Zharikov S, Tuttle KR, Short RA, Glushakova O, Ouyang X, Feig DI, Block ER, Herrera-Acosta J, et al: A causal role for uric acid in fructose-induced metabolic syndrome. Ame J Physiol Renal Physiol 2006, 290(3):F625-F631.

20. Tang W, Hong Y, Province MA, Rich SS, Hopkins PN, Arnett DK, Pankow JS, Miller MB, Eckfeldt JH: Familial clustering for features of the metabolic syndrome: the National Heart, Lung, and Blood Institute (NHLBI) Family Heart Study. Diabetes care 2006, 29(3):631-636.

21. Hammarsten J, Damber JE, Peeker R, Mellstrom D, Hogstedt B: A higher prediagnostic insulin level is a prospective risk factor for incident prostate cancer. Cancer Epidemiol 2010, 34(5):574-579.

22. Bjorge T, Lukanova A, Jonsson H, Tretli S, Ulmer H, Manjer J, Stocks T, Selmer R, Nagel G, Almquist M, et al: Metabolic syndrome and breast cancer in the me-can (metabolic syndrome and cancer) project. Cancer Epidemiol Biomarkers Prev 2010, 19(7):1737-1745.

23. Rose DP, Haffner SM, Baillargeon J: Adiposity, the metabolic syndrome, and breast cancer in African-American and white American women. Endocr Rev 2007, 28(7):763-777.

24. Giovannucci E: Metabolic syndrome, hyperinsulinemia, and colon cancer: a review. Am J Clin Nutr 2007, 86(3):S836-s842.

25. Siddiqui AA: Metabolic syndrome and its association with colorectal cancer: a review. The Am J Med Sci 2011, 341(3):227-231.

26. Shin HS, Lee HR, Lee DC, Shim JY, Cho KH, Suh SY: Uric acid as a prognostic factor for survival time: a prospective cohort study of terminally ill cancer patients. J Pain Symptom Manage 2006, 31(6):493-501.

27. Beavers KM, Beavers DP, Serra MC, Bowden RG, Wilson RL: Low relative skeletal muscle mass indicative of sarcopenia is associated with elevations in serum uric acid levels: findings from NHANES III. J Nutr Health Aging 2009, 13(3):177-182. 
28. Ward PC, McCarthy RD, Kilara A: Isolation of an inhibitor of hepatic cholesterolgenesis from human milk. Atheroscler 1982, 41(2-3):185-192.

29. Kolonel LN, Yoshizawa C, Nomura AM, Stemmermann GN: Relationship of serum uric acid to cancer occurrence in a prospective male cohort. Cancer Epidemiol Biomarkers Prev 1994, 3(3):225-228.

30. Strasak AM, Rapp K, Hilbe W, Oberaigner W, Ruttmann E, Concin H, Diem G, Pfeiffer KP, Ulmer H: Serum uric acid and risk of cancer mortality in a large prospective male cohort. Cancer Causes Control 2007, 18(9):1021-1029.

31. Strasak AM, Rapp K, Hilbe W, Oberaigner W, Ruttmann E, Concin H, Diem G, Pfeiffer KP, Ulmer $\mathrm{H}$ : The role of serum uric acid as an antioxidant protecting against cancer: prospective study in more than 28000 older Austrian women. Ann Oncol 2007, 18(11):1893-1897.

32. Strasak AM, Lang S, Kneib T, Brant LJ, Klenk J, Hilbe W, Oberaigner W, Ruttmann E, Kaltenbach L, Concin H, et al: Use of penalized splines in extended Cox-type additive hazard regression to flexibly estimate the effect of time-varying serum uric acid on risk of cancer incidence: a prospective, population-based study in 78,850 men. Ann Epidemiol 2009 19(1):15-24.

33. Lorincz AM, Sukumar S: Molecular links between obesity and breast cancer. Endocrine-related cancer 2006, 13(2):279-292.

34. Fernandez-Real JM, Pickup JC: Innate immunity, insulin resistance and type 2 diabetes. Trends Endocrinol Metab 2008, 19(1):10-16.

35. Grundy SM, Cleeman JI, Daniels SR, Donato KA, Eckel RH, Franklin BA, Gordon DJ, Krauss RM, Savage PJ, Smith SC Jr, et al: Diagnosis and management of the metabolic syndrome: an American Heart Association/National Heart, Lung, and Blood Institute Scientific Statement. Circulation 2005, 112(17):2735-2752.

36. Vona-Davis L, Howard-McNatt M, Rose DP: Adiposity, type 2 diabetes and the metabolic syndrome in breast cancer. Obes Rev 2007, 8(5):395-408.

37. Moller DE, Kaufman KD: Metabolic syndrome: a clinical and molecular perspective. Annual review of medicine 2005, 56:45-62.

38. Khunti K, Davies M: Metabolic syndrome. Bmj 2005, 331(7526):1153-1154.

39. Gil-Campos M, Aguilera CM, Canete $R$, Gil A: Uric acid is associated with features of insulin resistance syndrome in obese children at prepubertal stage. Nutr Hosp 2009, 24(5):607-613.

40. Abdullah AR, Hasan HA, Raigangar VL: Analysis of the relationship of leptin, high-sensitivity C-reactive protein, adiponectin, insulin, and uric acid to metabolic syndrome in lean, overweight, and obese young females. Metab Syndr Relat Disord 2009, 7(1):17-22.

41. Grayson PC, Kim SY, LaValley M, Choi HK: Hyperuricemia and incident hypertension: a systematic review and meta-analysis. Arthritis Care Res (Hoboken) 2011, 63(1):102-110.

42. Kodama S, Saito K, Yachi Y, Asumi M, Sugawara A, Totsuka K, Saito A, Sone H: Association between serum uric acid and development of type 2 diabetes. Diabetes care 2009, 32(9):1737-1742.

43. Pladevall M, Singal B, Williams LK, Brotons C, Guyer H, Sadurni J, Falces C, Serrano-Rios M, Gabriel R, Shaw JE, et al: A single factor underlies the metabolic syndrome: a confirmatory factor analysis. Diabetes care 2006, 29(1):113-122.

44. Johnson RJ, Perez-Pozo SE, Sautin YY, Manitius J, Sanchez-Lozada LG, Feig DI, Shafiu M, Segal M, Glassock RJ, Shimada M, et al: Hypothesis: could excessive fructose intake and uric acid cause type 2 diabetes? Endocr Rev 2009 , 30(1):96-116.

45. Boffetta $\mathrm{P}$, Nordenvall C, Nyren O, Ye W: A prospective study of gout and cancer. Eur J Cancer Prev 2009, 18(2):127-132.

46. Loh WJ, North BV, Johnston DG, Godsland IF: Insulin resistance-related biomarker clustering and subclinical inflammation as predictors of cancer mortality during 21.5 years of follow-up. Cancer Causes Control 2010, 21(5):709-718

47. Panero F, Gruden G, Perotto M, Fornengo P, Barutta F, Greco E, Runzo C, Ghezzo G, Cavallo-Perin P, Bruno G: Uric acid is not an independent predictor of cardiovascular mortality in type 2 diabetes: A populationbased study. Atherosclerosis 2012, 221(1):183-188.

48. Coughlin SS, Calle EE, Teras LR, Petrelli J, Thun MJ: Diabetes mellitus as a predictor of cancer mortality in a large cohort of US adults. Am $\mathrm{J}$ Epidemiol 2004, 159(12):1160-1167.

49. Capasso I, Esposito E, Pentimalli F, Crispo A, Montella M, Grimaldi M, De Marco M, Cavalcanti E, D'Aiuto M, Fucito A, et al: Metabolic syndrome affects breast cancer risk in postmenopausal women: National Cancer Institute of Naples experience. Cancer Biol Ther 2011, 10(12):1240-1243.
50. Rosato V, Bosetti C, Talamini R, Levi F, Montella M, Giacosa A, Negri E, La Vecchia C: Metabolic syndrome and the risk of breast cancer in postmenopausal women. Ann Oncol 2011.

51. Porto LA, Lora KJ, Soares JC, Costa LO: Metabolic syndrome is an independent risk factor for breast cancer. Arch Gynecol Obstet 2011, 284(5):1271-1276.

52. Kabat GC, Kim M, Chlebowski RT, Khandekar J, Ko MG, McTiernan A, Neuhouser ML, Parker DR, Shikany JM, Stefanick ML, et al: A longitudinal study of the metabolic syndrome and risk of postmenopausal breast cancer. Cancer Epidemiol Biomarkers Prev 2009, 18(7):2046-2053.

53. Oh SW, Park CY, Lee ES, Yoon YS, Park SS, Kim Y, Sung NJ, Yun YH, Lee KS, Kang HS, et al: Adipokines, insulin resistance, metabolic syndrome, and breast cancer recurrence: a cohort study. Breast Cancer Res 2011, 13(2):R34.

54. Pasanisi P, Berrino F, De Petris M, Venturelli E, Mastroianni A, Panico S: Metabolic syndrome as a prognostic factor for breast cancer recurrences. Int J Cancer 2006, 119(1):236-238.

55. Maiti B, Kundranda MN, Spiro TP, Daw HA: The association of metabolic syndrome with triple-negative breast cancer. Breast Cancer Res Treat 2010, 121(2):479-483.

56. Healy LA, Ryan AM, Carroll P, Ennis D, Crowley V, Boyle T, Kennedy MJ, Connolly E, Reynolds JV: Metabolic syndrome, central obesity and insulin resistance are associated with adverse pathological features in postmenopausal breast cancer. Clin Oncol (R Coll Radiol) 2010, 22(4):281-288

57. Elias AD: Triple-Negative Breast Cancer: A Short Review. Am J Clin Oncol 2010, 33(6):637-645

58. Gluz O, Liedtke C, Gottschalk N, Pusztai L, Nitz U, Harbeck N: Triple-negative breast cancer-current status and future directions. Ann Oncol 2009, 20(12):1913-1927.

59. Martinon F: Update on biology: uric acid and the activation of immune and inflammatory cells. Curr Rheumatol Rep 2010, 12(2):135-141.

60. Martinon F: Detection of immune danger signals by NALP3. J LeukOC Biol 2008, 83(3):507-511.

61. Kanellis J, Watanabe S, Li JH, Kang DH, Li P, Nakagawa T, Wamsley A, Sheikh-Hamad D, Lan HY, Feng L, et al: Uric acid stimulates monocyte chemoattractant protein-1 production in vascular smooth muscle cells via mitogen-activated protein kinase and cyclooxygenase-2. Hypertension 2003, 41(6):1287-1293.

62. Kang DH, Park SK, Lee IK, Johnson RJ: Uric acid-induced C-reactive protein expression: implication on cell proliferation and nitric oxide production of human vascular cells. J Am Soc Nephrol 2005, 16(12):3553-3562.

63. Sautin YY, Nakagawa T, Zharikov S, Johnson RJ: Adverse effects of the classic antioxidant uric acid in adipocytes: NADPH oxidase-mediated oxidative/nitrosative stress. Am J Physiol Cell Physiol 2007, 293(2):C584-596

64. Watanabe S, Kang DH, Feng L, Nakagawa T, Kanellis J, Lan H, Mazzali M, Johnson RJ: Uric acid, hominoid evolution, and the pathogenesis of saltsensitivity. Hypertens 2002, 40(3):355-360.

65. Corry DB, Eslami P, Yamamoto K, Nyby MD, Makino H, Tuck ML: Uric acid stimulates vascular smooth muscle cell proliferation and oxidative stress via the vascular renin-angiotensin system. J Hypertens 2008, 26(2):269-275

66. Yu MA, Sanchez-Lozada LG, Johnson RJ, Kang DH: Oxidative stress with an activation of the renin-angiotensin system in human vascular endothelial cells as a novel mechanism of uric acid-induced endothelial dysfunction. J Hypertens 2010, 28(6):1234-1242.

67. Baldwin W, McRae S, Marek G, Wymer D, Pannu V, Baylis C, Johnson RJ, Sautin YY: Hyperuricemia as a mediator of the proinflammatory endocrine imbalance in the adipose tissue in a murine model of the metabolic syndrome. Diabetes 2011, 60(4):1258-1269.

68. So A, Thorens B: Uric acid transport and disease. The J Clin Investig, 120(6):1791-1799.

69. Quan H, Peng X, Liu S, Bo F, Yang L, Huang Z, Li H, Chen X, Di W: Differentially expressed protein profile of renal tubule cell stimulated by elevated uric acid using SILAC coupled to LC-MS. Cell Physiol Biochem 2011, 27(1):91-98.

70. Simao AN, Lozovoy MA, Simao TN, Morimoto HK, Dichi I: Adiponectinemia is associated with uricemia but not with proinflammatory status in women with metabolic syndrome. J Nutr Metab 2012, 418094:418094. 
71. Becker S, Dossus L, Kaaks R: Obesity related hyperinsulinaemia and hyperglycaemia and cancer development. Arch Physiol Biochem 2009, 115(2):86-96.

72. Haluzik M, Parizkova J, Haluzik MM: Adiponectin and its role in the obesity-induced insulin resistance and related complications. Physiol Res 2004, 53(2):123-129.

73. Ryo M, Nakamura T, Kihara S, Kumada M, Shibazaki S, Takahashi M, Nagai M, Matsuzawa Y, Funahashi T: Adiponectin as a biomarker of the metabolic syndrome. Circ J 2004, 68(11):975-981.

74. Rolland YM, Perry HM 3rd: Patrick P, Banks WA, Morley JE: Leptin and adiponectin levels in middle-aged postmenopausal women: associations with lifestyle habits, hormones, and inflammatory markers-a crosssectional study. Metabolism 2006, 55(12):1630-1636.

75. Valle M, Martos R, Gascon F, Canete R, Zafra MA, Morales R: Low-grade systemic inflammation, hypoadiponectinemia and a high concentration of leptin are present in very young obese children, and correlate with metabolic syndrome. Diabetes Metab 2005, 31(1):55-62.

76. Rose DP, Komninou D, Stephenson GD: Obesity, adipocytokines, and insulin resistance in breast cancer. Obes Rev 2004, 5(3):153-165.

77. Wang Y, Lam JB, Lam KS, Liu J, Lam MC, Hoo RL, Wu D, Cooper GJ, Xu A: Adiponectin modulates the glycogen synthase kinase-3beta/betacatenin signaling pathway and attenuates mammary tumorigenesis of MDA-MB-231 cells in nude mice. Cancer Res 2006, 66(23):11462-11470.

78. Brakenhielm E, Veitonmaki N, Cao R, Kihara S, Matsuzawa Y, Zhivotovsky B, Funahashi T, Cao Y: Adiponectin-induced antiangiogenesis and antitumor activity involve caspase-mediated endothelial cell apoptosis. Proceedings of the National Academy of Sciences of the United States of America 2004, 101(8):2476-2481.

79. Duggan C, Irwin ML, Xiao L, Henderson KD, Smith AW, Baumgartner RN, Baumgartner KB, Bernstein L, Ballard-Barbash R, McTiernan A: Associations of insulin resistance and adiponectin with mortality in women with breast cancer. J Clin Oncol, 29(1):32-39.

80. Mantzoros C, Petridou E, Dessypris N, Chavelas C, Dalamaga M, Alexe DM, Papadiamantis Y, Markopoulos C, Spanos E, Chrousos G, et al: Adiponectin and breast cancer risk. J Clin Endocrinol Metab 2004, 89(3):1102-1107.

81. Miyoshi $Y$, Funahashi T, Kihara S, Taguchi T, Tamaki Y, Matsuzawa $Y$, Noguchi S: Association of serum adiponectin levels with breast cancer risk. Clin Cancer Res 2003, 9(15):5699-5704

82. Taliaferro-Smith L, Nagalingam A, Zhong D, Zhou W, Saxena NK, Sharma D: LKB1 is required for adiponectin-mediated modulation of AMPK-S6K axis and inhibition of migration and invasion of breast cancer cells. Oncogene 2009, 28(29):2621-2633.

83. Lam JB, Chow KH, Xu A, Lam KS, Liu J, Wong NS, Moon RT, Shepherd PR, Cooper GJ, Wang Y: Adiponectin haploinsufficiency promotes mammary tumor development in MMTV-PyVT mice by modulation of phosphatase and tensin homolog activities. PloS one 2009, 4(3):e4968.

84. Denzel MS, Hebbard LW, Shostak G, Shapiro L, Cardiff RD, Ranscht B: Adiponectin deficiency limits tumor vascularization in the MMTV-PyV-mT mouse model of mammary cancer. Clin Cancer Res 2009 15(10):3256-3264.

85. Jarde T, Perrier S, Vasson MP, Caldefie-Chezet F: Molecular mechanisms of leptin and adiponectin in breast cancer. Eur J Cancer 2011, 47(1):33-43.

86. Lyngdoh T, Marques-Vidal P, Paccaud F, Preisig M, Waeber G, Bochud M, Vollenweider P: Elevated serum uric acid is associated with high circulating inflammatory cytokines in the population-based Colaus study. PloS one 2011, 6(5):e19901.

87. Li Q, Yang Z, Lu B, Wen J, Ye Z, Chen L, He M, Tao X, Zhang W, Huang Y, et al: Serum uric acid level and its association with metabolic syndrome and carotid atherosclerosis in patients with type 2 diabetes. Cardiovasc Diabetol 2011, 10(72):ePMC3163178.

88. Frohlich M, Imhof A, Berg G, Hutchinson WL, Pepys MB, Boeing H, Muche R, Brenner $\mathrm{H}$, Koenig W: Association between C-reactive protein and features of the metabolic syndrome: a population-based study. Diabetes care 2000, 23(12):1835-1839.

89. Liu ZM, Ho SC: The association of serum C-reactive protein, uric acid and magnesium with insulin resistance in Chinese postmenopausal women with prediabetes or early untreated diabetes. Maturitas 2011, 70(2):176-181

90. Zapolski T, Wacinski P, Kondracki B, Rychta E, Buraczynska MJ, Wysokinski A: Uric acid as a link between renal dysfunction and both pro-inflammatory and prothrombotic state in patients with metabolic syndrome and coronary artery disease. Kardiol Pol 2011,

69(4):319-326.

91. Il'yasova D, Colbert LH, Harris TB, Newman AB, Bauer DC, Satterfield S, Kritchevsky SB: Circulating levels of inflammatory markers and cancer risk in the health aging and body composition cohort. Cancer Epidemiol Biomarkers Prev 2005, 14(10):2413-2418.

92. Panis C, Victorino VJ, Herrera AC, Freitas LF, De Rossi T, Campos FC, Simao AN, Barbosa DS, Pinge-Filho P, Cecchini R, et al: Differential oxidative status and immune characterization of the early and advanced stages of human breast cancer. Breast Cancer Res Treat 2012, 133(3):881-888.

93. Tsilidis KK, Branchini C, Guallar E, Helzlsouer KJ, Erlinger TP, Platz EA: $\mathrm{C}$-reactive protein and colorectal cancer risk: a systematic review of prospective studies. Int J Cancer 2008, 123(5):1133-1140.

94. Siemes C, Visser LE, Coebergh JW, Splinter TA, Witteman JC, Uitterlinden AG, Hofman A, Pols HA, Stricker BH: C-reactive protein levels, variation in the C-reactive protein gene, and cancer risk: the Rotterdam Study. J Clin Oncol 2006, 24(33):5216-5222.

95. Shimura T, Kitagawa M, Yamada T, Ebi M, Mizoshita T, Tanida S, Kataoka H, Kamiya T, Joh T: C-reactive protein is a potential prognostic factor for metastatic gastric cancer. Anticancer research 2012, 32(2):491-496.

96. Saito K, Kihara K: Role of C-reactive protein as a biomarker for renal cell carcinoma. Expert Rev Anticancer Ther 2010, 10(12):1979-1989.

97. Kanbay M, Ozkara A, Selcoki Y, Isik B, Turgut F, Bavbek N, Uz E, Akcay A, Yigitoglu R, Covic A: Effect of treatment of hyperuricemia with allopurinol on blood pressure, creatinine clearence, and proteinuria in patients with normal renal functions. Int Urol Nephrol 2007, 39(4):1227-1233.

98. Caravaca F, Martin MV, Barroso S, Cancho B, Arrobas M, Luna E, SanchezCasado E: Serum uric acid and C-reactive protein levels in patients with chronic kidney disease. Nefrologia 2005, 25(6):645-654.

99. Allin KH, Nordestgaard BG, Zacho J, Tybjaerg-Hansen A, Bojesen SE: Creactive protein and the risk of cancer: a mendelian randomization study. J Natl Cancer Inst 2010, 102(3):202-206.

100. Allin $\mathrm{KH}$, Nordestgaard BG: Elevated C-reactive protein in the diagnosis, prognosis, and cause of cancer. Crit Rev Clin Lab Sci 2011, 48(4):155-170.

101. Bedir A, Topbas M, Tanyeri F, Alvur M, Arik N: Leptin might be a regulator of serum uric acid concentrations in humans. Jpn Heart J 2003, 44(4):527-536

102. Fruehwald-Schultes B, Peters A, Kern W, Beyer J, Pfutzner A: Serum leptin is associated with serum uric acid concentrations in humans. Metabolism 1999, 48(6):677-680.

103. Zhang Y, Proenca R, Maffei M, Barone M, Leopold L, Friedman JM: Positional cloning of the mouse obese gene and its human homologue. Nature 1994, 372(6505):425-432.

104. Klok MD, Jakobsdottir S, Drent ML: The role of leptin and ghrelin in the regulation of food intake and body weight in humans: a review. Obes Rev 2007, 8(1):21-34.

105. Tesch GH, Lim AK: Recent insights into diabetic renal injury from the $\mathrm{db} /$ $\mathrm{db}$ mouse model of type 2 diabetic nephropathy. Am J Physiol Renal Physiol 2011, 300(2):F301-310.

106. Piestrzeniewicz K, Luczak K, Komorowski J, Maciejewski M, Goch JH: The relationship between leptin and obesity and cardiovascular risk factors in men with acute myocardial infarction. Cardiol J 2007, 14(3):252-259.

107. Bo S, Gambino R, Durazzo M, Ghione F, Musso G, Gentile L, Cassader M, Cavallo-Perin P, Pagano G: Associations between serum uric acid and adipokines, markers of inflammation, and endothelial dysfunction. $J$ Endocrinol Invest 2008, 31(6):499-504.

108. Samara A, Herbeth B, Aubert R, Berrahmoune H, Fumeron F, Siest G, VisvikisSiest S: Sex-dependent associations of leptin with metabolic syndromerelated variables: the Stanislas study. Obesity (Silver Spring) 2010, 18(1):196-201

109. Matsubara M, Chiba H, Maruoka S, Katayose S: Elevated serum leptin concentrations in women with hyperuricemia. J Atheroscler Thromb 2002, 9(1):28-34.

110. Lin JD, Chiou WK, Chang HY, Liu FH, Weng HF: Serum uric acid and leptin levels in metabolic syndrome: a quandary over the role of uric acid. Metabolism 2007, 56(6):751-756.

111. Inokuchi T, Tsutsumi Z, Takahashi S, Ka T, Moriwaki Y, Yamamoto T: Increased frequency of metabolic syndrome and its individual metabolic abnormalities in Japanese patients with primary gout. $J$ Clin Rheumatol 2010, 16(3):109-112. 
112. Lanaspa M, Sautin Y, Ejaz A, Madero M, Le M, Manitius J, Sanchez-Lozada LG, Nakagawa T, Johnson RJ: Uric acid and Metabolic Syndrome: What is the relationship? Curr Rheum Rev 2011, 7:162-169.

113. Khandekar MJ, Cohen P, Spiegelman BM: Molecular mechanisms of cancer development in obesity. Nat Rev Cancer 2011, 11(12):886-895.

114. Grossmann ME, Ray A, Nkhata KJ, Malakhov DA, Rogozina OP, Dogan S, Cleary MP: Obesity and breast cancer: status of leptin and adiponectin in pathological processes. Cancer Metastasis Rev 2010, 29(4):641-653.

115. Han C, Zhang HT, Du L, Liu X, Jing J, Zhao X, Yang X, Tian B: Serum levels of leptin, insulin, and lipids in relation to breast cancer in china. Endocr 2005, 26(1):19-24.

116. Snoussi K, Strosberg AD, Bouaouina N, Ben Ahmed S, Helal AN, Chouchane L: Leptin and leptin receptor polymorphisms are associated with increased risk and poor prognosis of breast carcinoma. BMC Cancer 2006, 6:38.

117. Dieudonne MN, Machinal-Quelin F, Serazin-Leroy V, Leneveu MC, Pecquery R, Giudicelli Y: Leptin mediates a proliferative response in human MCF7 breast cancer cells. Biochem Biophys Res Commun 2002, 293(1):622-628.

118. Caulfield MJ, Munroe PB, O'Neill D, Witkowska K, Charchar FJ, Doblado M, Evans S, Eyheramendy S, Onipinla A, Howard P, et al: SLC2A9 is a highcapacity urate transporter in humans. PLOS Med 2008, 5(10):e197.

119. Anzai N, Ichida K, Jutabha P, Kimura T, Babu E, Jin CJ, Srivastava S, Kitamura K, Hisatome I, Endou $\mathrm{H}$, et al: Plasma urate level is directly regulated by a voltage-driven urate efflux transporter URATV1 (SLC2A9) in humans. J Biol Chem 2008, 283(40):26834-26838.

120. Ni Z, Bikadi Z, Rosenberg MF, Mao Q: Structure and function of the human breast cancer resistance protein (BCRP/ABCG2). Curr Drug Metab 2010, 11(7):603-617.

121. Woodward OM, Kottgen A, Coresh J, Boerwinkle E, Guggino WB, Kottgen M: Identification of a urate transporter, $\mathrm{ABCG} 2$, with a common functional polymorphism causing gout. Proceedings of the National Academy of Sciences of the United States of America 2009, 106(25):10338-10342.

122. Dehghan A, Kottgen A, Yang Q, Hwang SJ, Kao WL, Rivadeneira F, Boerwinkle E, Levy D, Hofman A, Astor BC, et al: Association of three genetic loci with uric acid concentration and risk of gout: a genomewide association study. Lancet 2008, 372(9654):1953-1961.

123. Yamagishi K, Tanigawa T, Kitamura A, Kottgen A, Folsom AR, Iso H: The rs2231142 variant of the ABCG2 gene is associated with uric acid levels and gout among Japanese people. Rheumatol (Oxford) 2010 49(8):1461-1465.

124. Matsuo H, Takada T, Ichida K, Nakamura T, Nakayama A, Ikebuchi $Y$, Ito K, Kusanagi Y, Chiba T, Tadokoro S, et al: Common defects of ABCG2, a highcapacity urate exporter, cause gout: a function-based genetic analysis in a Japanese population. Sci Transl Med 2009, 1(5):5ra11.

125. Korenaga $Y$, Naito K, Okayama N, Hirata H, Suehiro $Y$, Hamanaka $Y$ Matsuyama H, Hinoda Y: Association of the BCRP C421A polymorphism with nonpapillary renal cell carcinoma. Int J Cancer 2005, 117(3):431-434

126. Hu LL, Wang XX, Chen X, Chang J, Li C, Zhang Y, Yang J, Jiang W, Zhuang SM BCRP gene polymorphisms are associated with susceptibility and survival of diffuse large B-cell lymphoma. Carcinog 2007, 28(8):1740-1744.

127. Wang F, Liang YJ, Wu XP, Chen LM, To KK, Dai CL, Yan YY, Wang YS, Tong XZ, Fu LW: Prognostic value of the multidrug resistance transporter ABCG2 gene polymorphisms in Chinese patients with de novo acute leukaemia. Eur J Cancer 2011, 47(13):1990-1999.

128. Agarwal A, Banerjee A, Banerjee UC: Xanthine oxidoreductase: a journey from purine metabolism to cardiovascular excitation-contraction coupling. Crit Rev Biotechnol 2011, 31(3):264-280.

129. Linder N, Lundin J, Isola J, Lundin M, Raivio KO, Joensuu H: Down-regulated xanthine oxidoreductase is a feature of aggressive breast cancer. Clin Cancer Res 2005, 11(12):4372-4381.

130. Linder N, Haglund C, Lundin M, Nordling S, Ristimaki A, Kokkola A, Mrena J, Wiksten JP, Lundin J: Decreased xanthine oxidoreductase is a predictor of poor prognosis in early-stage gastric cancer. J Clin Pathol 2006, 59(9):965-971.

131. Linder N, Martelin E, Lundin M, Louhimo J, Nordling S, Haglund C, Lundin J: Xanthine oxidoreductase - clinical significance in colorectal cancer and in vitro expression of the protein in human colon cancer cells. Eur $J$ Cancer 2009, 45(4):648-655.

132. Linder $N$, Butzow R, Lassus $H$, Lundin M, Lundin J: Decreased xanthine oxidoreductase (XOR) is associated with a worse prognosis in patients with serous ovarian carcinoma. Gynecol Oncol 2012, 124(2):311-318.

133. Kim AW, Batus M, Myint R, Fidler MJ, Basu S, Bonomi P, Faber LP, Wightman SC, Warren $\mathrm{WH}, \mathrm{Mclntire} \mathrm{M}$, et al: Prognostic value of xanthine oxidoreductase expression in patients with non-small cell lung cancer. Lung Cancer 2011, 71(2):186-190

134. Ikegami T, Natsumeda Y, Weber G: Decreased concentration of xanthine dehydrogenase (EC 1.1.1.204) in rat hepatomas. Cancer Res 1986, 46(8):3838-3841

135. Sun AS, Cederbaum Al: Oxidoreductase activities in normal rat liver, tumor-bearing rat liver, and hepatoma HC-252. Cancer Res 1980 40(12):4677-4681.

136. Fini MA, Orchard-Webb D, Kosmider B, Amon JD, Kelland R, Shibao G, Wright RM: Migratory activity of human breast cancer cells is modulated by differential expression of xanthine oxidoreductase. J Cell Biochem 2008, 105(4):1008-1026.

137. Fini MA, Monks J, Farabaugh SM, Wright RM: Contribution of Xanthine Oxidoreductase to Mammary Epithelial and Breast Cancer Cell Differentiation In Part Modulates Inhibitor of Differentiation-1. Mol Cancer Res 2011, 9(9):1242-1254.

138. Shen Z, Ye Y, Bin L, Yin M, Yang X, Jiang K, Wang S: Metabolic syndrome is an important factor for the evolution of prognosis of colorectal cancer: survival, recurrence, and liver metastasis. Am J Surg 2010, 200(1):59-63.

139. Braun S, Bitton-Worms K, LeRoith D: The link between the metabolic syndrome and cancer. Int J Biol Sci 2011, 7(7):1003-1015.

140. Tan S, Radi R, Gaudier F, Evans RA, Rivera A, Kirk KA, Parks DA: Physiologic levels of uric acid inhibit xanthine oxidase in human plasma. Pediatr Res 1993, 34(3):303-307.

141. Tsimberidou AM, Keating MJ: Hyperuricemic syndromes in cancer patients. Contrib Nephrol 2005, 147:47-60.

142. Tiu RV, Mountantonakis SE, Dunbar AJ, Schreiber MJ Jr: Tumor lysis syndrome. Semin Thromb Hemost 2007, 33(4):397-407.

143. Han HJ, Lim MJ, Lee YJ, Lee JH, Yang IS, Taub M: Uric acid inhibits renal proximal tubule cell proliferation via at least two signaling pathways involving PKC, MAPK, cPLA2, and NF-kappaB. Am J Physiol Renal Physiol 2007, 292(1):F373-381.

144. Rao GN, Corson MA, Berk BC: Uric acid stimulates vascular smooth muscle cell proliferation by increasing platelet-derived growth factor A-chain expression. J Biol Chem 1991, 266(13):8604-8608.

145. Kang DH, Han L, Ouyang X, Kahn AM, Kanellis J, Li P, Feng L, Nakagawa T, Watanabe $S$, Hosoyamada $M$, et al: Uric acid causes vascular smooth muscle cell proliferation by entering cells via a functional urate transporter. Am J Nephrol 2005, 25(5):425-433.

146. Cheung KJ, Tzameli I, Pissios P, Rovira I, Gavrilova O, Ohtsubo T, Chen Z Finkel T, Flier JS, Friedman JM: Xanthine oxidoreductase is a regulator of adipogenesis and PPARgamma activity. Cell Metab 2007, 5(2):115-128.

147. Gibbings S, Elkins ND, Fitzgerald H, Tiao J, Weyman ME, Shibao G, Fini MA, Wright RM: Xanthine Oxidoreductase Promotes the Inflammatory State of Mononuclear Phagocytes through Effects on Chemokine Expression, Peroxisome Proliferator-activated Receptor-\{gamma\} Sumoylation, and HIF-1\{alpha\}. J Biol Chem 2011, 286(2):961-975.

148. Augustin R, Carayannopoulos MO, Dowd LO, Phay JE, Moley JF, Moley KH: Identification and characterization of human glucose transporter-like protein-9 (GLUT9): alternative splicing alters trafficking. J Biol Chem 2004, 279(16):16229-16236.

149. Kushiyama A, Okubo H, Sakoda H, Kikuchi T, Fujishiro M, Sato H, Kushiyama S, Iwashita M, Nishimura F, Fukushima T, et al: Xanthine Oxidoreductase Is Involved in Macrophage Foam Cell Formation and Atherosclerosis Development. Arterioscler Thromb Vasc Biol 2012, 32(2):291-298.

150. Wright RM, Ginger LA, Kosila N, Elkins ND, Essary B, McManaman JL, Repine JE: Mononuclear phagocyte xanthine oxidoreductase contributes to cytokineinduced acute lung injury. Am J Respiratory Cell Mole Biol 2004, 30(4):479-490.

151. Torres M, Forman HJ: Redox signaling and the MAP kinase pathways. Biofactors 2003, 17(1-4):287-296.

152. Xu X, Rao GS, Groh V, Spies T, Gattuso P, Kaufman HL, Plate J, Prinz RA Major histocompatibility complex class I-related chain A/B (MICA/B) expression in tumor tissue and serum of pancreatic cancer: role of uric acid accumulation in gemcitabine-induced MICA/B expression. BMC Cancer 2011, 11(1):194.

153. Alef MJ, Vallabhaneni R, Carchman E, Morris SM Jr, Shiva S, Wang Y, Kelley EE, Tarpey MM, Gladwin MT, Tzeng E, et al: Nitrite-generated NO circumvents dysregulated arginine/NOS signaling to protect against intimal hyperplasia in Sprague-Dawley rats. The J Clin Investig 2011, 121(4):1646-1656.

154. Jung JW, Song WJ, Kim YS, Joo KW, Lee KW, Kim SH, Park HW, Chang YS, Cho SH, Min KU, et al: HLA-B58 can help the clinical decision on starting 
allopurinol in patients with chronic renal insufficiency. Nephrol Dial Transplant 2011, 26(11):3567-3572.

155. Preitner F, Bonny O, Laverriere A, Rotman S, Firsov D, Da Costa A, Metref S, Thorens B: Glut9 is a major regulator of urate homeostasis and its genetic inactivation induces hyperuricosuria and urate nephropathy. Proceedings of the National Academy of Sciences of the United States of America 2009, 106(36):15501-15506.

doi:10.1186/2001-1326-1-16

Cite this article as: Fini et al:: Contribution of uric acid to cancer risk, recurrence, and mortality. Clinical and Translational Medicine 2012 1:16.

Submit your manuscript to a SpringerOpen ${ }^{\circ}$ journal and benefit from:

- Convenient online submission

- Rigorous peer review

- Immediate publication on acceptance

- Open access: articles freely available online

- High visibility within the field

- Retaining the copyright to your article

Submit your next manuscript at $>$ springeropen.com 